\title{
Dealing with Zinc and Iron Deficiency in Rice: Combine Strategies to Fight Hidden Hunger in Developing Countries
}

\author{
Ritasree Sarma ${ }^{*}$, H.V. Vijaya Kumara Swamy and H.E. Shashidhar \\ Department of Plant Biotechnology, University of Agricultural Science, \\ GKVK, Bengaluru, Karnataka, India \\ *Corresponding author
}

A B S T R A C T

Keywords

Iron, Zinc,

Biofortification,

Malnutrition

Article Info

Accepted:

16 February 2018

Available Online:

10 March 2018
Zinc and Iron are essential micronutrient for both plant growth and human health but it is often reported to be deficient in regions where rice is use as staple food. Although significant progresses are made in understanding genetic and molecular mechanism of micronutrient acquisition but these need to be characterize to increase the bioavailability of these micronutrients. Biofortification is suggested to be a sustainable and costeffective approach in this perspective and for that combination of various agronomic and genetic strategies should be put in place without delay.

\section{Introduction}

Rice is the primary staple food for more than half the world's population and together they directly supply more than $50 \%$ of all calories consume by the entire human population (Jia-Yang et al., 2014). Total rice production is increases to 751.9 million tonnes worldwide (FAO, 2017) and among that 90 percent is produce and consume in developing countries. But unfortunately, about 870 million people are suffering from chronic undernourishment globally (Da Silva et al., 2013) and vast majority of them are from developing countries where rice is closely associated with food security and political stability. So, improving the micronutrient status of rice is very important to tackle key nutrition and health related problems of these large numbers of populations, most notably developing countries.
Among the various micronutrients, iron $(\mathrm{Fe})$ and zinc ( $\mathrm{Zn})$ are important for both plant growth and human health. In developing countries, iron and zinc deficiencies are reported to be the sixth and fifth highest health risk factor respectively (Freitas et al., 2016; Sharma et al., 2013) causing a high mortality rates. So, overcoming these nutritional deficiencies is need of hour.

Various strategies to improve micronutrient status include food supplementation, food fortification and biofortification (Masuda et al., 2013). Among them biofortification is appears to be the most feasible, sustainable and economical as poor families of developing countries cannot afford other strategies (Nakandalage et al., 2016). For this, selection of effective genetic and crop management approach is of utmost importance. 


\section{Importance of zinc}

\section{Role in plants}

Zinc is one of the key micronutrient involve in regulating various biological and physiological processes in plants. In rice tissues, typical zinc concentration is around 35 to $100 \mathrm{ppm}$ and deficiency symptoms appear when concentration drops below $20 \mathrm{ppm}$. Zinc deficiency affects photosynthesis due to altered chloroplast pigments (Table 1) (Samreen et al., 2017) and results in short internodes, decrease in leaf size and delayed maturity, sterile spikes, leaves with brown botches and streaks (Abdullah, 2015).

Further it reduces pollen viability leading to fewer grain set and severe yield penalties worldwide (Disante et al., 2010).

\section{Impact in human health}

Zinc is one of the important trace elements whose role in human health is undisputable. Cellular zinc homeostasis is important for proper release and action of insulin (Rutter et al., 2016), modulating oxidative stress and various age-related disorder (Prasad, 2013). Insufficient intake of zinc in humans include emotional disorder, weight loss, dysfunctions, atherosclerosis, several malignancies, alopecia, diarrhea (Rutter et al., 2016, Chasapis et al., 2012) decline in immune competence and certain neurological and physiological problem (Roohani et al., 2013).

\section{Importance of iron}

\section{Role in plants}

Iron is one of the important micronutrient that requires to maintain proper metabolic and physiological processes in plants. It acts as cofactor for many enzymes and proteins of mitochrondria and chloroplast and hence it has major role in life sustaining processes like photosynthesis and respiration. It has role in scavenging of ROS and act as key element to ensure electron flow through the PSIIb6f/Rieske-PSI complex in choloroplast (Zargar et al., 2015). Further insufficient iron uptake leads to iron deficiency symptoms such as interveinal yellowing and chlorosis of emerging leaves, less dry matter production, reduced sugar metabolism enzymes (El-Jendoubi et al., 2014; Das, 2014), seed dormancy (Murgia et al., 2017).

\section{Impact in human health}

Iron is the most abundant transition metal involve in various biological processes. Almost two-thirds of the body iron is found in the hemoglobin present in circulating erythrocytes, $25 \%$ is contained in a readily mobilizable iron store and the remaining $15 \%$ is bound to myoglobin in muscle tissue and in a variety of enzymes involved in the oxidative metabolism and many other cell functions (IOM, 2001).

Abnormal iron homoeostasis can induce cellular damage through hydroxyl radical production which can cause the oxidation and modification of lipids, proteins, carbohydrates, DNA and leads to various neuro generative diseases like Alzheimer's disease and Parkinson's disease (Ward et al., 2014). Further iron deficiency anaemia is a major problem affecting around 2 billion people in both developed and developing countries (WHO, 2016).

Table.1 Chlorophyll contents $\left(\mathrm{mg} \mathrm{kg}^{-1}\right)$ on dry weight basis in mungbean varieties at different concentrations of $\mathrm{Zn}$ in solution culture

\begin{tabular}{lccccc}
\hline Zn treatment & V1 & V2 & V3 & V4 & Mean \pm St.dv \\
\hline Control & $35.7 \mathrm{f}$ & $73.45 \mathrm{de}$ & $93.12 \mathrm{~cd}$ & $105.93 \mathrm{c}$ & $78.55 \mathrm{~b} 30.63$ \\
$1 \mu \mathrm{M}$ & $36.81 \mathrm{f}$ & $145.30 \mathrm{~b}$ & $210.82 \mathrm{a}$ & $221.01 \mathrm{a}$ & $153.5 \mathrm{a} 84.71$ \\
$2 \mu \mathrm{M}$ & $64.54 \mathrm{e}$ & $146.07 \mathrm{~b}$ & $210.57 \mathrm{a}$ & $226.08 \mathrm{a}$ & $161.9 \mathrm{a} 73.52$ \\
Mean \pm St.dv & $45.69 \mathrm{c}$ & $123.6 \mathrm{~b}$ & $171.5 \mathrm{a}$ & $184.4 \mathrm{a}$ & \\
& 16.34 & 41.71 & 67.88 & 67.95 & \\
\hline
\end{tabular}

V1 = Ramazan, V2 = Swat mungI, V3 = NM92, V4 = KMI.St. d = standard deviation. The mean followed by similar letter (s) are not significantly different at $P=0.05$. 
Table 2. Effect of different forms of foliar $\mathrm{Zn}$ fertilization on the percentages of solubility, retention, transported and uptake efficiency of $\mathrm{Zn}$ among three rice cultivars

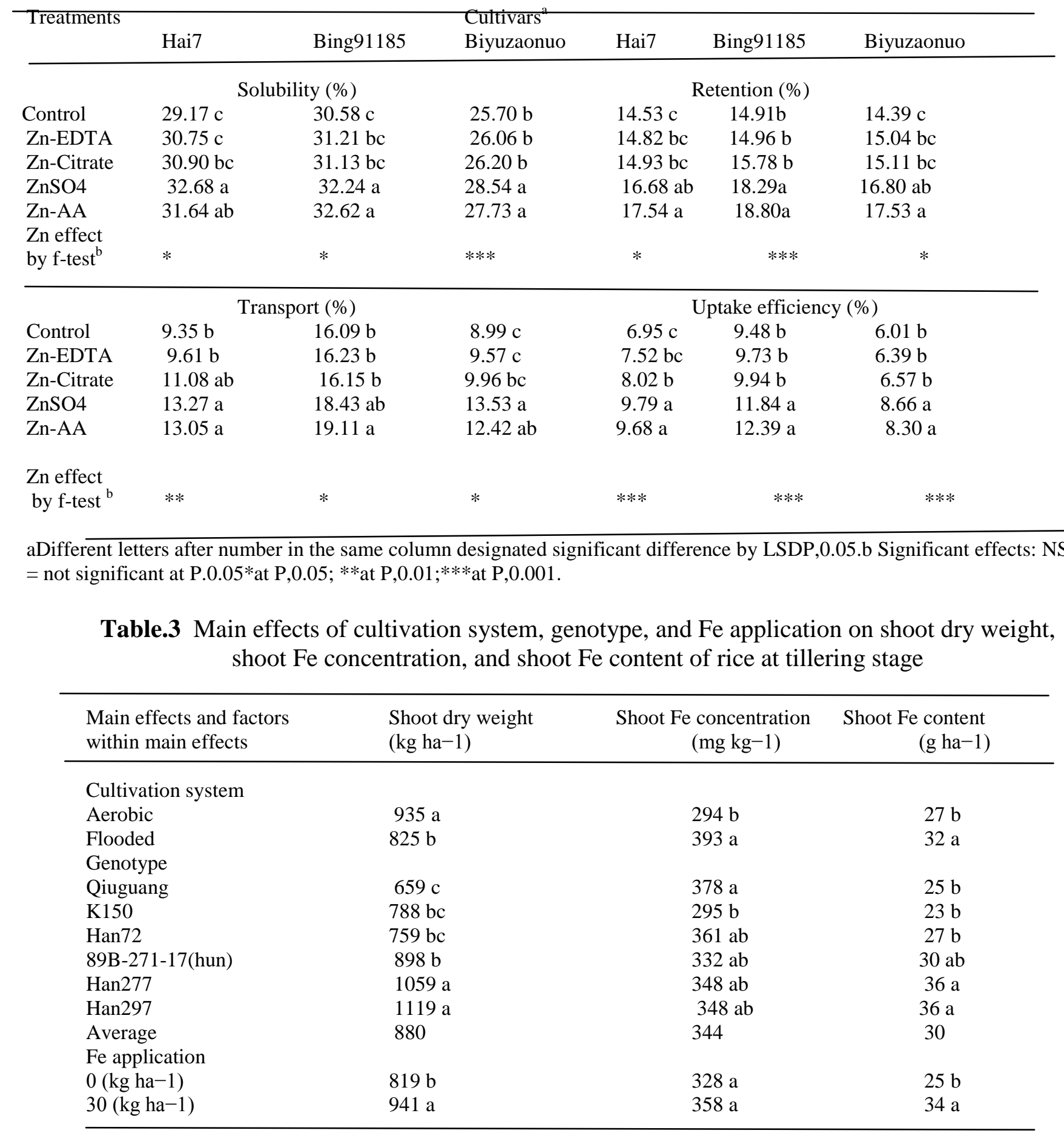

For each main effect, values in a column followed by the same letter are not significantly different $(P>0.05)$. 
Table $4 \mathrm{Zn}$ concentrations in shoot and root of rice under different water regimes and $\mathrm{Zn}$ source treatments

\begin{tabular}{clcccc}
\hline \multirow{2}{*}{ Genotype } & \multicolumn{2}{c}{ Zn treatment } & \multicolumn{2}{c}{ Shoot Zn concentration $(\mathrm{mg} / \mathrm{kg})$} & \multicolumn{2}{c}{ Root Zn concentration $(\mathrm{mg} / \mathrm{kg})$} \\
& & $\mathrm{CF}$ & AWD & CF & AWD \\
Nipponbar & Control & $50.2 \mathrm{~b}$ & $54.6 \mathrm{~b}$ & $86.9 \mathrm{c}$ & $90.7 \mathrm{c}$ \\
& ZnSO4 & $60.7 \mathrm{a}$ & $63.6 \mathrm{a}$ & $130.6 \mathrm{a}$ & $143.9 \mathrm{a}$ \\
& Zn-EDTA & $59.6 \mathrm{a}$ & $61.3 \mathrm{a}$ & $119.5 \mathrm{~b}$ & $117.7 \mathrm{~b}$ \\
& Mean & $56.9 \mathrm{~B}$ & $59.8 \mathrm{~B}$ & $112.3 \mathrm{~A}$ & $117.5 \mathrm{~B}$ \\
\hline Jiaxing27 & Control & $62.0 \mathrm{~b}$ & $65.3 \mathrm{~b}$ & $96.2 \mathrm{c}$ & $102.1 \mathrm{~b}$ \\
& ZnSO4 & $68.7 \mathrm{a}$ & $72.6 \mathrm{a}$ & $144.5 \mathrm{a}$ & $153.5 \mathrm{a}$ \\
& Zn-EDTA & $66.2 \mathrm{ab}$ & $71.5 \mathrm{a}$ & $130.0 \mathrm{~b}$ & $149.9 \mathrm{a}$ \\
& Mean & $65.6 \mathrm{~A}$ & $69.8 \mathrm{~A}$ & $123.6 \mathrm{~A}$ & $135.1 \mathrm{~A}$ \\
\hline
\end{tabular}

Within a column, means followed by different letters are significantly different at $P<0.05$ according to Duncan's multiple range test. Lower-case and upper-case letters indicate comparisons among three $\mathrm{Zn}$ treatments and between two genotypes, respectively

Table 5 Iron and $\mathrm{Zn}$ concentrations in individual plant tissues of transgenic progeny classified as high-yield(CHY) and low-yield(CLY)in the OE-OsNAS/IR64 and OE-OsNAS/Esp progenies

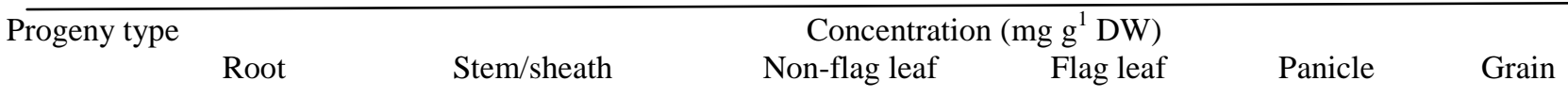

$\begin{array}{llllllllllll}\mathrm{Fe} & \mathrm{Zn} & \mathrm{Fe} & \mathrm{Zn} & \mathrm{Fe} & \mathrm{Zn} & \mathrm{Fe} & \mathrm{Zn} & \mathrm{Fe} & \mathrm{Zn} & \mathrm{Fe} & \mathrm{Zn}\end{array}$

\begin{tabular}{|c|c|c|c|c|c|c|c|c|c|c|c|c|}
\hline \multicolumn{13}{|l|}{ OE-OsNAS/IR64 } \\
\hline NS ( $n$ D 3) & 6267 & 18.7 & 273 & 7.8 & 237 & 10.2 & 205 & $9.8 \mathrm{~b}$ & $89 b$ & $16.9 \mathrm{~b}$ & $14.4 \mathrm{~b}$ & $15.3 \mathrm{~b}$ \\
\hline$+\mathrm{C} \mathrm{HY}(n \mathrm{D} 6)$ & 7350 & 18.5 & 258 & 12.0 & 251 & 10.6 & 2131 & $1.3 \mathrm{~b}$ & $107 \mathrm{ab}$ & $11.1 \mathrm{~b}$ & $18.0 \mathrm{~b}$ & $23.2 \mathrm{~b}$ \\
\hline$+\mathrm{LY}(n \mathrm{D} 4)$ & 9150 & 22.5 & 283 & 26.2 & 253 & 15.6 & 193 & $16.6 \mathrm{a}$ & $122 \mathrm{a}$ & $34.6 \mathrm{a}$ & $28.8 \mathrm{a}$ & $55.9 \mathrm{a}$ \\
\hline $\begin{array}{l}P \text {-value (progenytyp) } \\
O E-O S N A S / E s p\end{array}$ & n.s. & n.s. & n.s & .n.s. & n.s & .n.s. & n.s. & $* *$ & $*$ & $* *$ & $* *$ & $* * *$ \\
\hline $\mathrm{NS}(n \mathrm{D} 3)$ & 8000 & 25.0 & 207 & 9.0 & 295 & 13.2 & 295 & 15.2 & 155 & 10.0 & $16.1 \mathrm{~b}$ & $20.2 b$ \\
\hline + HY (n D 10) & 8120 & 43.4 & 234 & 19.0 & 337 & 13.7 & 296 & 17.9 & 157 & 15.2 & $28.6 \mathrm{a}$ & $38.3 \mathrm{a}$ \\
\hline + LY(n D 3) & 6333 & 59.0 & 243 & 16.0 & 423 & 10.53 & 201 & 4.2 & 173 & 16.13 & $6.1 \mathrm{a}$ & $63.0 \mathrm{a}$ \\
\hline$P$-value (progenytyp) & n.s. & n.s. & n.s & .n.s. & n.s & .n.s. & n.s. & n.s. & n.s. & $\mathrm{n} . \mathrm{s}$ & $* * *$ & $* * *$ \\
\hline
\end{tabular}

n.s.,not significant.Within each column,values with different letters represent significant differences between progeny type at the $5 \%$ leve lbyHochberg'sGT2test.The values givenaremeans. ${ }^{*} \mathrm{P}<0.05, * * \mathrm{P}<0.01, * * * \mathrm{P}<0.001$. NS,nullsegregants;DW, dryweigh

Agronomic strategy for improving iron and zinc uptake

\section{Application of fertilizers}

Nitrogen (N) is an essential macronutrient (Sarwar et al., 2010) which helps to improve translocation of other micronutrients like iron and zinc in various plants. Better $\mathrm{N}$ nutrition promotes protein synthesis, which is a major sink for $\mathrm{Fe}$ and $\mathrm{Zn}$ and enhances the expression
$\mathrm{Zn}$ and Fe transporter proteins, such as ZIP family transporters (Cakmak et al., 2010), YSL protein synthesis and nitrogenous compounds formation, such as NA and DMA, both of which participate in $\mathrm{Zn}$ and $\mathrm{Fe}$ transport in rice (Slamet-Loedin et al., 2015). So, application of $\mathrm{N}$ fertilizer could improve $\mathrm{Fe}$ and $\mathrm{Zn}$ in rice grains but effect varies depending on genotypic different and rate or method of application. Split application of nitrogen fertilizer in proper time corresponding to plant requirement found to be 
effective and help to increase Fe content of rice grain and enhance rice grain nutritional value (Fei et al., 2008). $\mathrm{N}$ fertilizer rate combined with $\mathrm{Zn}$ application method show a clear increase in both grain yield and $\mathrm{Zn}$ content as the $\mathrm{N}$ fertilizer level increased from 200 to 300 $\mathrm{kg} / \mathrm{ha}$. Fe and $\mathrm{Zn}$ content in different parts of rice plant may be affected by nitrogen fertilizer thus increasing the nitrogen fertilizer up to $160 \mathrm{~kg} / \mathrm{ha}$ has reported to improve $\mathrm{Fe}$ and $\mathrm{Zn}$ concentrations in brown rice by $28.96 \%$, and $16.0 \%$ for IR64 and by $22.16 \%$ and $20.21 \%$ for IR68144 compared with control (Hao et al., 2007).

An estimation of soil $\mathrm{Zn}$ and application of $\mathrm{Zn}$ fertilizer to $\mathrm{Zn}$ deficit soil is important for $\mathrm{Zn}$ biofortification (Mallikarjuna Swamy et al., 2016). But the response to $\mathrm{Zn}$ fertilizer has been shown to differ across rice genotypes, methods of application and soil conditions (White et al., 2011). Foliar application of $\mathrm{Zn}$ fertilizers has shown better results than soil application for increasing grain $\mathrm{Zn}$ concentration, but the magnitude of this increase is not consistent across genotypes (Table 2) (Mabesa et al., 2013). Application of Fe fertilizer is direct and effective method for enhancing Fe content in rice grain (Li et al., 2016). Among the various iron forms chelated iron sulphates results in higher root iron concentrations while a higher leaf iron concentration is observed when iron citrate is used. Effects of foliar application of different forms of iron fertilizer at different plant developmental stages are studied in rice and it is shown that application of the synthetic chelating agents like DTPA-Fe form at the anthesis stage results in about $20 \%$ increase in iron content of polished rice grains ( $\mathrm{He}$ et al., 2013). In addition to grain iron concentration, iron fertilization positively influences the grain zinc concentration in rice and wheat (Zeidan et al., 2010, Zaigham et al., 2014)

\section{Water management}

Rice is a semi aquatic crop grown under lowland condition but as the fresh water crisis increasing day by day, rice is now grown under various irrigation management options like always aerobic, always anaerobic and many variations along the aerobic-anaerobic spectrum (Bouman et al., 2007). In aerobic conditions, rice is grown as a dry field-crop in irrigated not in flooded, fertile soils (Gao et al., 2006). But shifting from anaerobic to aerobic condition has benefits and risking of micronutrient status of grains in different soil types which need to be understand. In aerobic conditions nitrogen is uptake as nitrate which may cause an imbalance in the cation/anion ratio, resulting in exudation of $\mathrm{OH}^{-}$into the rhizosphere with a subsequent rise in soil $\mathrm{pH}$ and redox potential. A higher redox potential can accumulate much more oxidized $\mathrm{Fe}^{3+}$ which is not readily available for plant uptake (Zuo et al., 2011).

While in flooding condition, Fe- oxides are dissolved when the $\mathrm{Fe}^{3+}$ is reduced to $\mathrm{Fe}^{2+}$ which weakens the oxide stability and increases its water-solubility (Kirk, 2004).

This releases much more $\mathrm{Fe}$ into the soil solution which is nearly sufficient for plant uptake. In both aerobic and flooded condition, application of ferrous sulphate significantly increases shoot $\mathrm{Fe}$ concentration and shoot $\mathrm{Fe}$ content at tillering stage but at physiological maturity, grain iron is found significantly lower in aerobic than in flooded plots (Table 3) (Xiaoyun et al., 2012).

Under anaerobic conditions, $\mathrm{Zn}$ forms as insoluble zinc sulphide (Bostick et al., 2001) and insoluble carbonate mixtures (Kirk, 2004) which plant cannot uptake. While increase oxidation under aerobic condition decrease $\mathrm{Zn}$ precipitation as $\mathrm{ZnS}$ (Carbonell-Barrachina et $a l ., 2000)$ and further increase availability of iron oxidizing/reducing bacteria, AM fungi associated with root-induced rhizosphere processes such as exudation of $\mathrm{Zn}$ chelators and have positive effect on nutrient availability (Gao et al., 2017).

Alternative wetting and drying (AWD) is one of the promising water saving technology which is widely adapted in many rice producing 
countries (Lampayan et al., 2015). It combines both the beneficial effects of aerobic and anaerobic cultivation system which potentially decrease water inputs by 5\%-35\% when compared with Continuous flooding (CF) with the yield of rice grain either being maintained (Chapagain et al., 2010).

Although for iron, it does not seem to be promising for increasing iron content in grain (Nortona et al., 2017) but shows effective for increment of grain zinc content alone or when combine with various zinc fertilizer treatments (Table 4) (Wang et al., 2014).

\section{Breeding and transgenics approach}

Plant breeding (e.g., genetic biofortification) approach is thought to be the cost effective and eco- friendly approach for improving micronutrient status of rice in developing countries. For developing variety with high micronutrient, germ plasm screening is done initially to find out the genetic variation among the existing genetic resource (Slamet-Loedin et al., 2015, Howarth et al., 2017). There is abundant genetic variation for the grain $\mathrm{Zn}$ and Fe concentration in both brown and polished grains in the rice germplasm. Different wild relatives, landraces, aus and aromatic accessions, deep water rice and coloured rice are the best sources of high grain $\mathrm{Zn}$. Wild species of rice such as $O$. nivara, $O$. rufipogon, O. latifolia, $O$. officinalis, and $O$. granulata also contain high amounts of $\mathrm{Zn}$, around 2-3 fold higher than in the cultivated rice with $\mathrm{Zn}$ concentration varying from $37 \mathrm{mg} / \mathrm{kg}$ to 55 $\mathrm{mg} / \mathrm{kg}$ in non-polished grains (Impa et al., 2013; Anuradha et al., 2012; Banerjee et al., 2010).

The world's first $\mathrm{Zn}$ enriched rice variety is released in 2013 by the Bangladesh Rice Research Institute (BRRIdhan62), which is claimed to contain $20-23 \mathrm{mgZnkg}^{-1}$ for brown rice (Harvest plus, 2015) while another variety by Directorate of Rice Research (DRR-Dhan $45)$ is released in India with over all mean zinc content of $22.6 \mathrm{ppm}$ in polished rice, develop through conventional breeding without compromising yield using the material from Harvest Plus (Balasubramanian, 2016). While in case of iron, rice germplasm has a very narrow genetic variability for endosperm iron content. Iron content changes depending on varieties, IR64 (12.58-12.88mg/Kg), Jasmine 85 $(12.84-18.50 \mathrm{mg} / \mathrm{Kg})$ and OMCS2000 (11.77$14.78 \mathrm{mg} / \mathrm{Kg}$ ) and about $2 / 3$ of iron is lost through milling (Tran et al., 2004). Other advance strategy like mutation breeding also gaining importance in this regard. A number of IR64 mutants produced by the treatment with Sodium azide, a mutagen, is reported to have high Zn. Three IR64 mutant lines viz., M-IR180, M-IR-49 and M-IR-175 has more than 26 $\mathrm{mg} \mathrm{kg}-1 \mathrm{Zn}$ in polished rice as against $16 \mathrm{mg}$ $\mathrm{kg}-1$ in IR64 has been reported (Jeng et al., 2012) A combinatorial approach using both hybridization and induced mutation is also found to be effective to develop new cultivar expressing several improved traits like improve aroma and high iron content (Cua, 2016).

Although various approaches are trying from last 15 years to reach the $30 \%$ EAR (Estimated Average Requirement) nutritional targets for iron and zinc concentrations in polished rice grains (Bouis et al., 2011) but still it remains a major challenge. This $30 \%$ EAR was calculated as $13 \mu \mathrm{g} \mathrm{g}-1 \mathrm{Fe}$ and $28 \mu \mathrm{g} \mathrm{g}-1 \mathrm{Zn}$ in polished grains taking into account of $90 \%$ micronutrient retention after processing and $10 \%$ bioavailability for $\mathrm{Fe}$ and $25 \%$ bioavailability for Zn (Trijatmiko et al., 2016). In this aspect transgenic approach can be a better option.

Several studies exhibit the associated increase in $\mathrm{Fe}$ and $\mathrm{Zn}$ content in rice grain by over expression or activation of various transporters genes. Over expression of three rice NAS homologous proteins, (OsNAS1, OsNAS2, and OsNAS3) resulted in 2-fold increase in Fe and $\mathrm{Zn}$ concentration in polished rice (Sasaki et al., 2014) while over expression of OsHMA3 enhance the uptake of $\mathrm{Zn}$ by up regulating the ZIP family genes in the roots (Johnson et al., 2011). 
Combined improvement of iron, zinc and $\beta$ carotene content in rice endosperm are improve by expressing Arabidopsis Nicotianamine Synthase 1 (Atnas1), Bean Ferritin (PvFERRITIN), bacterial Carotene Desaturase (CRTI) and maize PHYTOENE Synthase (ZmPSY) in a single genetic locus (Singh et al., 2017).

High yielding rice line with $\mathrm{Zn}$ and $\mathrm{Fe}$ biofortified in polished grains can also be develop by overexpressing OsNAS2 in various genotypes (Table 5) (Singh et al., 2017) Further field evaluation of transgenic events is also reported to be successful without a yield penalty or altered grain quality where NASFer-274 containing rice (OsNAS2) and soybean ferritin $(\mathrm{SferH}-1)$ genes is use in a single locus insertion (Cua, 2016).

Iron and zinc deficiency are the most common type of micronutrient malnutrition where population of all groups in all the region of world is get affected. So, for effective and sustainable solution of this problem a complete understanding of iron and zinc uptake, translocation and further allocation to reproductive organs is needed. Agronomic interventions for increment of micronutrient status are effective but it is erratic, depends on cultivar and environment.

Genetic intervention is a cost effective and sustainable strategy but for that further exploitation of wide genetic variety of rice germplasm is necessary. Consequently, new combined agronomic and genetic strategy should be developed to address this problem of malnutrition for people whose staple diet is rice.

\section{References}

Abdullah, A.S., 2015. Zinc Availability and Dynamics in the Transition from Flooded to Aerobic Rice Cultivation. J Plant Biol Soil Health. 2(1): 2-5.

Anuradha, K., Agarwal, S., Batchu, A.K., Babu, A.P., Swamy, B.P.M., Longva, T., Sarla,
N. 2012. Evaluating rice germplasm for iron and zinc concentration in brown rice and seed dimensions. J Geophys Res. 4:19-25.

Balasubramanian.2016. Biofortification: Micronutrient built in grains. The Hindu http://www.thehindu.com/sci-tech/ science/Biofortification-Micronutrientbuilt-in grains/article14572744.ece. Accessed 16 April 2016

Banerjee, S., Sharma, D.J., Verulkar, S.B., Chandel, G. 2010. Use of in silico and semi quantitative RT-PCR approaches to develop nutrient rich rice (Oryza sativa $\mathrm{L}$ ) India. J Biotechnol. 9:203-212.

Bostick, B.C., Hansel, C.M., La Force, M.J., Fendorf, S. 2001. Seasonal fluctuations in zinc speciation within a contaminated wetland. Environ Sci Techno. 35: 38233829.

Bouis, H.E., Hotz, C., McClafferty, B., Meenakshi, J.V., and Pfeiffer, W.H. 2011. Biofortification: a new tool to reduce micronutrient malnutrition. Food Nutr Bull. 32: 31-40.

Bouman, B., Barker, R., Humphreys, E., Tuong, T. P., Atlin, G., Bennett J et al., 2007. Rice: Feeding the billion. In Water for Food, Water for Life: a Comprehensive Assessment of Water Management in Agriculture (Eds). Molden D editor (London: Earthscan and Colombo: International Water Management Institute). Pp. 515-549.

Cakmak, I., Pfeiffer, W.H., Mc Clafferty, B. 2010. Biofortifcation of durum wheat with zinc and iron. Cereal Chem. 87: 1020.

Carbonell-Barrachina, A. A., Jugsujinda, A., Burlo, F., Delaune, R. D., Patrick Jr, W.H. 2000. Arsenic chemistry in municipal sewage sludge as affected by redox potential and $\mathrm{pH}$. Water Res. 34:216-224.

Chapagain, T., Yamaji, E. 2010. The effects of irrigation method, age of seedling and spacing on crop performance, productivity and water-wise rice 
production in Japan. M. Paddy Water Environ. 8(1): 81-90.

Chasapis, C.T., Loutsidou, A.C., Spiniopoulou, C.A., Stefanidou, M.E. 2012. Zinc and human health: an update. Archi. toxicol.86:521-534.

Cua, Q.H. 2016. Biotechnologies for Plant Mutation Breeding. Springer International.

Da Silva, J.G. 2013. Food losses means hunger. The think. Eat. Save. Reduce your footprint-campaign of the save food initiative is a partnership between UNEP, FAO and Messe Dusseldorf. http://www.unep.org/ourplanet/2013/ma y/en/pdf/article3.pdf. Accessed 8 November 2013

Das, S.K., 2014. Role of micronutrient in rice cultivation and management strategy in organic agriculture-A Reappraisal. Agricultural Sciences. 5: 765-769.

Disante, K.B., Fuentes, D., Cortina, J. 2010. Response to drought of Zn-stressed Quercus suber L. Seedlings. Environ Expr Bot. 70:96-103.

El-Jendoubi, H., Vazquez, S., Calatayud, A., Vavpetic, P., Vogel-Mikus, K., Pelicon, P., Abadía, J., Abadia, A., Morales, F. 2014. The effects of foliar fertilization with iron sulfate in chlorotic leaves are limited to the treated area. A study with peach trees (Prunus persica L. Batsch) grown in the field and sugar beet (Beta vulgaris L.) grown in hydroponics. Front Plant Sci. 5: 1-16.

FAO. 2017. Rice market monitor. http://www. fao.org/fileadmin/templates/est/COMM_ MARKETS_MONITORING/Rice/Image s/RMM/RMMAPR17H.pdf. Accessed 11 April. 2017

Fei, X., Zhong, W., Yun-jie, G., Gang, C., Peng, Z. 2008. Effects of nitrogen application time on caryopsis development and grain quality variety Yangdao6. Rice Science. 15(1): 57-62.

Freitas, B.A., Lima, L.M., Moreira, M.E., Priore, S.E., Henriques, B.D., Carlos, C.F., Sabino, J.S., Franceschini, Sdo. C. 2016. Micronutrient supplementation adherence and influence on the prevalence of anemia and iron, zinc and vitamin A deficiencies in preemies with a corrected age of six months. Clinics. 71(8):440-448

Gao, X., Chunqin, Z., Xiaoyun, F., Fusuo, Z., and Ellis, H. 2006. From flooded to aerobic conditions in rice cultivation: Consequences for zinc uptake. Plant and Soil.280:41-47.

Gao, X., Kuyper, T.W., Zou, C., Zhang, F., Hoffland, E. (2007). Mycorrhizal responsiveness of aerobic rice genotypes is negatively correlated with their zinc uptake when nonmycorrhizal. Plant and Soil. 290: 283-291.

Hao, H., Wei, Y., Ying, X., Wu, F.2007. Effects of Different Nitrogen Fertilizer Levels on $\mathrm{Fe}, \mathrm{Mn}, \mathrm{Cu}$ and $\mathrm{Zn}$ Concentrations in Shoot and Grain Quality in Rice (Oryza sativa).Rice Science.14(4): 289-294.

Harvestplus2015. Bangladesh releases new, improved zinc rice variety. Harvest Plus, Washington, DC (2015)

He, W., Shohag, M.J., Wei, Y., Feng, Y., Yang, X. 2013. Iron concentration, bioavailability, and nutritional quality of polished rice affected by different forms of foliar iron fertilizer. Food Chem. 141:4122-4126.

Howarth, E.B., Amy, S.2017. Improving nutrition through biofortification: A review of evidence from Harvest Plus, 2003 through 2016. Global Food Security 12: 49-58.

Impa, S.M., Morete, M.J., Ismail, A.M., Schulin, R., Johnson-Beebout, S.E. 2013. $\mathrm{Zn}$ uptake translocation and grain $\mathrm{Zn}$ loading in rice (Oryza sativa $\mathrm{L}$ ) genotypes selected for Zn-deficiency tolerance and high grain Zn. J Exp Bot. 64:2739-2751.

Jeng, T.L., Lin, Y.W., Wang, C.S., Sung, J.M. 2012. Comparisons and selection of rice mutants with high iron and zinc contents in their polished grains that were mutated from the indica type cultivar IR64. J Food Compos Anal. 28:149-154.

Jia-Yang, L., Jun, W., Robert, S.Z. 2014.The 3,000 rice genomes project: new 
opportunities and challenges for future rice research.Giga Science. 3(8):1-3.

Johnson, A. A., Kyriacou, B., Callahan, D.L., Carruthers, L., Stangoulis, J., Lombi, E., Tester, M. 2011. Constitutive overexpression of the OsNAS gene family reveals single-gene strategies for effective iron-and zinc-biofortification of rice endosperm. PLoS ONE. 6(24476): 111.

Kirk, G., 2004. The Biogeochemistry of Submerged Soils. Chichester: Wiley.

Lampayan, R.M., Rejesus, R.M., Singleton, G.R., Bouman, B.A.M. 2015. Adoption and economics of alternate wetting and drying water management for irrigated lowland rice. Field Crop Res. 170: 95108.

Lei, G., Jiadong, C.,Ruijie, C.,Hubo, L., Hongfei, L., Longxing, T., and Jie, X. 2016. Comparison on cellular mechanisms of iron and cadmium accumulation in rice: prospects for cultivating $\mathrm{Fe}$-rich but $\mathrm{Cd}$-free rice.Rice. 9(39): 1-12.

Mabesa, R.L., Impa, S.M., Grewal, D., Johnson-Beebout. 2013. Contrasting grain zinc response of biofortification rice (Oryza sativa $\mathrm{L}$ ) breeding lines to foliar $\mathrm{Zn}$ application. Field Crop Res. 2(149):223-233.

Mallikarjuna Swamy, B.P.M., Rahman, M., Inabangan-Asilo, M.A., Amparado, A., Manito, C., Mohanty, P.C., Reinke, R., Slamet-Loedin, I.H. 2016. Advances in breeding for high grain Zinc in Rice. Rice. 9(49): 1-16.

Masuda, H., Aung, M.S., Nishizawa, N.K.2013. In biofortification of rice using different transgenic approaches. Rice. 6(40): 1-12.

Murgia, I., and Morandini, P. 2017. Iron deficiency prolongs seed dormancy in Arabidopsis Plants. Front Plant Sci. 8: 15.

Nakandalage, N., Nicola, S.M., Norton, R.M., Hirotsu, N., Milham, P.J., Seneweera, S. 2016. Improving Rice Zinc Biofortification Success Rates Through
Genetic and Crop Management Approaches in a Changing Environment. Frontiers in Plant Science. 7(764):1-13.

Nortona, G.J., Shafaei, M., Travis, A.J., Deacona, C.M., Dankua, J., Ponda, D., Cochranea, N., Lockhart, K et al., 2017. Impact of alternate wetting and drying on rice physiology, grain production, and grain quality. Field Crops Research. 205: $1-13$.

Prasad, A.S., 2013. Discovery of Human Zinc Deficiency: Its impact on human health and diseases. Adv Nutr. 4(2): 176-190.

Roohani, N., Hurrell, R., Kelishadi, R., Schulin, R. 2013. Zinc and its importance for human health: An integrative review. J Res Med Sci. 18:144-157.

Rutter, G.A., Chabosseau, P., Bellomo, E.A., Maret, W.,Mitchell, R.K., Hodson, D.A., Solomou, A., and Hu, M. 2016. Intracellular zinc in insulin secretion and action: a determinant of diabetes risk? Proceed Nutrl Soc., 75: 61-72.

Samreen, T., Hamid, H., Saleem, U., Muhammad, U., Javid. 2017. Zinc effect on growth rate, chlorophyll, protein and mineral contents of hydroponically grown mungbeans plant (Vigna radiata). Arabian J Chem. 10: 1802-1807.

Sarwar, N., Saifullah., Malhi, S.S., Zia, M.H., Naeem, A., Bibi. S., Farid, G. 2010. Role of mineral nutrition in minimizing cadmium accumulation by plants. J Sci Food Agric. 90(6):925-937.

Sasaki, A., Yamaji, N., Ma, J.F. 2014. Over expression of OsHMA3 enhances $\mathrm{Cd}$ tolerance and expression of $\mathrm{Zn}$ transporter genes in rice. J Exp Bot. 65:6013-6021.

Sharma, A., Patni, B., Shankhdhar, D., and Shankhdha, S.C. 2013. Zinc-An indispensable micronutrient. Physiol. Mol. Biol, Plants. 19(1): 11-20.

Singh, S.P., Gruissem, W., and Bhullar, N.K. 2017. Single genetic locus improvement of iron, zinc and $\beta$-carotene content in rice grains. Scientific Reports. 7:1-11.

Slamet-Loedin, I.H., Johnson-Beebout, S.E., Impa, S., Tsakirpaloglou, N. 2015. Enriching rice with $\mathrm{Zn}$ and $\mathrm{Fe}$ while 
minimizing Cd risk. Front Plant Sci. 6(121): 1-9.

Tran, T., Hoa, C., Nguyen, T., Phong, L. 2004. Effect of milling technology on iron content in rice grains of some leading varieties in the Mekong Delta. Omonrice. $12: 38-44$.

Trijatmiko, K.R., Duenas, C., Tsakirpaloglou, N., Torrizo, L., Arines, FM., Adeva,C., Balindong, J., Oliva, N., Sapasap, M.V., Borrero, J et al., 2016. Biofortified indica rice attains iron and zinc nutrition dietary targets in the field. Sci Rep. 6 (19792): 113.

Wang, Y., Wei, Y., Dong, Y., Lu, L., Feng, Y., Zhang, J., Pan, F., Yang, X. 2014. Improved yield and $\mathrm{Zn}$ accumulation for rice grain by $\mathrm{Zn}$ fertilization and optimized water management. Biomed \& Biotechnol. 15(4): 365-374.

Ward, R.J., Zucca, F.A., Duyn, J.H., Crichton, R.R., Zecca, L. 2014. The role of iron in brain ageing and neurodegenerative disorders. Lancet Neurol. 13(10):10451060.

Washington, DC: National Academy Press; 2001. IOM. Institute of Medicine. Iron. In: Dietary Reference Intakes for Vitamin A, Vitamin K, Arsenic, Boron, Chromium, Copper, Iodine, iron, Manganese, Molybdenum, Nickel, Silicon, Vanadium, and Zinc., pp. 290 393.
White, P.J., Braodley, M.R. 2011. Physiological limits to zinc biofortification of edible crops. Front Plant Sci. 2(80):1-11.

WHO (2016). Iron deficiency anaemia. http://www.who.int/nutrition/topics/ida/en . Accessed 29 August 2016.

Xiaoyun, F., Md. Rezaul, K., Xinping, C., Yueqiang, Z., Xiaopeng, G., Fusuo, Z., Chunqin, Z. 2012. Growth and iron uptake of lowland and aerobic rice genotypes under flooded and aerobic cultivation. Commun Soil Sci Plant Anal. 43:1811-1822.

Zaigham, S., Hatem, R., Allah, R. 2014. Combating Mineral Malnutrition through Iron and Zinc Biofortification of Cereals. Compr Rev Food Sci F. 13(3)329-347.

Zargar, S.M., Mahajan, R., Farhat, S., Nazir, M., Mir, R.A., Nazir, M., Salgotra, R.A., Mallick, S.A. 2015. Understanding the role of Iron and Zinc in animals and crop plants from genomics perspective. Current trends biotechnology pharmacy. 9(2) 182-195.

Zeidan, M.S., Mohamed, M.F., Hamouda, H.A. 2010. Effect of foliar fertilization of $\mathrm{Fe}$, $\mathrm{Mn}$ and $\mathrm{Zn}$ on wheat yield and quality in low sandy soils fertility. World J Agric Sci. 6:696-699.

Zuo, Y., Zhang, F. 2011. Soil and crop management strategies to prevent iron deficiency in crops. Plant Soil. 339 8395.

\section{How to cite this article:}

Ritasree Sarma, H.V. Vijaya Kumara Swamy and Shashidhar, H.E. 2018. Dealing with Zinc and Iron Deficiency in Rice: Combine Strategies to Fight Hidden Hunger in Developing Countries. Int.J.Curr.Microbiol.App.Sci. 7(03): 1887-1895.

doi: https://doi.org/10.20546/ijcmas.2018.703.224 